\title{
Antibodies against spotted fever group Rickettsia sp., in horses of the colombian Orinoquia
}

\author{
Anticuerpos contra Rickettsia sp., del grupo de las fiebres \\ manchadas en equinos de la Orinoquía colombiana
}

\author{
Diego A. Riveros-Pinilla, ${ }^{1 *}$ MVZ, Leidy Acevedo G, ${ }^{2}$ Microbióloga, Andrés F. Londoño, ${ }^{2}$ \\ M.Sc, Agustín Góngora O, ${ }^{3}$ Dr.Sci.
}

${ }^{1}$ Joven Investigador, Universidad de los Llanos. 2 Universidad de Antioquia, Facultad de Ciencias Agrarias, Grupo de Investigación en Ciencias Veterinarias "Centauro", Línea de zoonosis emergentes y re-emergentes, Medellín, Colombia. 'Universidad de los Llanos, Escuela de Ciencias Animales, Villavicencio, Colombia. *Correspondence: diegoriverosmvz@ hotmail.com

Received: October 2014; Acepted: March 2015.

\begin{abstract}
Objective. It was determined the presence of antibodies against Rickettsia sp. of the spotted fever group, in horses of 8 municipalities of the Colombian Orinoquia. Matherials and methods. A cross-sectional study was conducted on 246 sera from apparently healthy horses and processed by the indirect immunofluorescence test (IFI). Results. General seropositivity was $(2.85 \% ; 7 / 246)$, while by municipalities the results were, Arauca $(9.1 \% ; 2 / 22)$, Saravena $(5.6 \% ; 1 / 18)$, San José del Guaviare $(4.9 \% ; 2 / 41)$, San Martín $(3.8 \% ; 1 / 26)$, Yopal $(1.9 \% ; 1 / 52)$. It was not identified the presence of antibodies in Puerto López $(0 / 52)$, Puerto Gaitán $(0 / 15)$ and Villavicencio $(0 / 20)$. Four of the positive samples presented titles of $1: 64$, while the remaining $31: 128$. Conclusions. It shows the circulation of Rickettsia sp. of the Spotted Fever Group in horses in the region of the Colombian Orinoquia, suggesting the need for further studies to understand the ecoepidemiology of municipalities with presence of seropositive.
\end{abstract}

Key words: Horses, rickettsia, serology, zoonoses. (Fuente:DeC).

\section{RESUMEN}

Objetivo. Determinar la presencia de anticuerpos contra Rickettsia sp. del grupo de las fiebres manchadas, en equinos de 8 municipios de la Orinoquía Colombiana. Materiales y métodos. Se realizó un estudio transversal en 246 sueros equinos provenientes de animales aparentemente sanos y procesados por la técnica de inmunofluorescencia indirecta (IFI). Resultados. La seropositividad general fue $(2.85 \% ; 7 / 246)$, por municipios la seropositividad fue Arauca $(9.1 \% ; 2 / 22)$, Saravena $(5.6 \% ; 1 / 18)$, San José del Guaviare $(4.9 \% ; 2 / 41)$, San Martín $(3.8 \% ; 1 / 26)$ y Yopal $(1.9 \% ; 1 / 52)$. No se identificó la presencia de seropositivos en Puerto López (0/52), Puerto Gaitán (0/15) y Villavicencio $(0 / 20)$. Cuatro de las muestras positivas presentaron títulos de 1:64, mientras las 3 restantes de $1: 128$. No se encontró asociación entre los títulos serológicos con la raza, el sexo, edad y actividad zootécnica. Conclusiones. Se demuestra la circulación de Rickettsia sp. del Grupo de las Fiebres Manchadas en equinos de la región de la Orinoquía Colombiana, sugiriendo la necesidad de nuevos estudios para entender la ecoepidemiología de los municipios con presencia de reactores serológicos.

Palabras clave: Caballos, rickettsia, serología, zoonosis. (Fuente:DeC). 


\section{INTRODUCTION}

Rickettsioses make up a group of bacterial zoonotic diseases unknown to the majority of the Colombian population. The genus Rickettsia has been classified into four groups: the typhus group (TG) which includes the Rickettsia prowazekii species that causes typhus, transmitted by lice, and Rickettsia typhi, which causes typhus or murine typhus, transmitted by fleas; the ancestral group (AG) composed of Rickettsia canadensis and Rickettsia bellii, and the transitional group (TG) which is composed of the Rickettsia australis, Rickettsia felis and Rickettsia akari species. The fourth group is known as the Spotted Fever group (SFG), where about 20 tickborne species are included (1).

Within the SFG, Rickettsia rickettsii is the most virulent and causes a disease, which, depending on the region, is given the name: Rocky Mountain Spotted Fever (RMSF) in North America, Brazilian Spotted Fever in Brazil, Spotted Fever in Mexico and Tobia Fever in Colombia (2).

Bacteria of the Rickettsia spp. genus are intracellular microorganisms that principally infect endothelial cells in humans and cause acute febrile symptoms that can be deadly if not appropriately treated. Clinical signs produced by these bacteria are similar to those of other tropical diseases, principally from the hemorrhagic or icterohemorrhagic fever group, which in many cases inhibits a timely diagnosis (3).

Diseases caused by the Rickettsia genus occur worldwide and have been recognized for many years; presently they are considered to be either emergent or re-emergent diseases and, in humans, vary in terms of severity (4). In the majority of reported cases in different countries, a common factor relating to the occurrence of the disease is poverty and environmental transformation (5).

In Colombia, the name Tobia Fever comes from the name given to an outbreak that occurred between the years 1934-1936 in the village of Tobia, in the Nimaima municipality (Cundinamarca). In the outbreak, 62 of the 65 people infected (of different ages) died, which represents a $95 \%$ mortality rate (6). Following this event, the disease was not known to surface again until the $21^{\text {st }}$ century, where other fatal cases appeared in Villeta, Cundinamarca in 2003 and 2004 (7), Necoclí, Antioquia in 2006 (8), Los Córdobas, Córdoba in 2007 (9) and Turbo, Antioquia in 2008 (10).

\section{INTRODUCCIÓN}

Las rickettsiosis comprenden un grupo de enfermedades bacterianas, de tipo zoonótico poco conocidas por la mayoría de la población colombiana. El género Rickettsia se ha clasificado en cuatro grupos; el grupo tifo (GT) que incluye las especies Rickettsia prowazekii que causa el tifo epidémico, transmitido por piojos y Rickettsia typhi que ocasiona el tifo endémico o murino, trasmitido por pulgas; el grupo ancestral (GA) compuesto por Rickettsia canadensis y Rickettsia bellii, el grupo transicional (GTR) que se compone de las especies Rickettsia australis, Rickettsia felis y Rickettsia akari. El cuarto grupo, se conoce como grupo de las fiebres manchadas (GFM), en donde se incluyen alrededor de 20 especies que son trasmitidas por garrapatas (1).

Dentro del GFM, Rickettsia rickettsii es la más virulenta y ocasiona una enfermedad que según el lugar de presentación recibe el nombre de Fiebre Manchada de las Montañas Rocosas (FMMR) en América del Norte, Fiebre Manchada Brasilera en Brasil, Fiebres Manchadas en México y Fiebre de Tobia en Colombia (2).

Las bacterias del género Rickettsia spp., son microorganismos intracelulares obligados que infectan principalmente células endoteliales en los humanos y ocasionan cuadros febriles agudos que pueden ser letales sino reciben tratamiento adecuado. Los signos clínicos producidos por esta bacteria son compartidos con otras enfermedades tropicales, principalmente del grupo de las fiebres hemorrágicas o ictero-hemorrágicas, lo que en muchas ocasiones no permite realizar un diagnóstico oportuno (3).

Las enfermedades ocasionadas por el género Rickettsia se presentan en todo el mundo y han sido reconocidas desde la antigüedad; en la actualidad se consideran como enfermedades emergentes o reemergentes y cursan con un grado variable de severidad en los humanos (4). En la mayoría de los casos reportados en los diferentes países, un factor común para que la enfermedad se presente, son las condiciones de pobreza de la población y la transformación ambiental (5).

En Colombia, el nombre de Fiebre de Tobia obedece a la denominación que se dio a un brote ocurrido durante los años 1934-1936 en la localidad de Tobia, municipio de Nimaima (Cundinamarca). En el brote murieron 62 personas (de diferentes edades) de 65 infectadas, lo que representó una letalidad del $95 \%$ (6). A partir de este evento, no se volvió a tener conocimiento de la enfermedad hasta inicios del siglo XXI, con la presentación de 
Different epidemiological studies confirm the importance of canines and horses as sentinels to indicate the circulation of Rickettsia sp. $(11,12)$, especially horses, since they are one of the most important hosts for Amblyomma cajennense, (ticks that are the principal vector for RMSF in Central and South America). Horses can be infected and become a serological reactor, for which they become "evidence" of the circulation of the bacteria in the site of origin $(13,14)$.

The national program of epidemiological surveillance of febrile cases and dengue of the Ministry of Health, in samples from humans originating from Guaviare between the years 2001-2004, found the prevalence of antibodies (Ab), using $R$. rickettsii antigen, of $(4.7 \%)$ (15). In the small town of Pachaquiaro near the municipality of Puerto López (Meta) the prevalence in humans was (59\%), which was associated with the possible transmission of Rickettsia sp. by ectoparasites (16). Previous studies confirm the presence of the etiological agent in the region of Orinoquia, but at the same time show that there are very few prior studies done on this topic with domestic animals, which suggests the need for further studies in this area of knowledge.

The objective of this study was to determine the presence of antibodies against SFG Rickettsia $\mathrm{sp}$. in horses from the 8 municipalities of the Orinoquia region of Colombia.

\section{MATERIALS AND METHODS}

Type of study and samples. A descriptive cross-sectional study was made in 246 equine sera from 8 Orinoquia municipalities. The sera were part of the inventory of a bank of sera from the Laboratory of Breeding and Animal Genetics of the University of Los Llanos. The samples had been obtained from horses that were reportedly healthy between the months of July- August in the year 2013 and were maintained at a temperature of $-70^{\circ} \mathrm{C}$ in a deep freezer (Revco ${ }^{\circledR}$, Asheville, NC, USA). At the time of collecting the sera, information about age, sex, breed and Zootechnical activity was also gathered.

The serums came from the municipalities in Villavicencio (8.2\%), Puerto López $(21.1 \%)$, Puerto Gaitán $(6.1 \%)$, Yopal $(21.1 \%)$, San Martín (10.6\%), San José del Guaviare (16.7\%), Saravena (7.3\%) and Arauca (9.1\%) figure 1. nuevos casos fatales en Villeta, Cundinamarca en los años 2003 y 2004 (7), Necoclí, Antioquia en 2006 (8), Los Córdobas, Córdoba en 2007 (9) y Turbo, Antioquia en 2008 (10).

Diferentes estudios epidemiológicos han evidenciado la importancia de los caninos y los equinos como centinelas para el monitoreo de circulación de Rickettsia sp. $(11,12)$. Especialmente los equinos, ya que es uno de los hospederos más importantes para Amblyomma cajennense, (garrapata que es el vector principal para FMMR en Centro y Suramérica). Los equinos pueden sufrir la infección y volverse un reactor serológico, por lo cual se convierten en "evidencia" de la circulación de la bacteria en el sitio de procedencia $(13,14)$.

El programa nacional de vigilancia epidemiológica de eventos febriles y del dengue del Ministerio de Salud, en muestras de humanos provenientes del Guaviare entre los años 2001-2004, encontró una prevalencia de anticuerpos (Ac), usando antígeno de $R$. rickettsii, de (4.7\%) (15). En el corregimiento de Pachaquiaro cerca del Municipio de Puerto López (Meta) la prevalencia en humanos fue de $(59 \%)$, la cual fue asociado con la posible transmisión de Rickettsia sp., por ectoparásitos (16). Los anteriores estudios ponen en evidencia la presencia del agente etiológico en la región de la Orinoquía, pero al mismo tiempo muestra que son pocos los estudios previos en animales domésticos que se han hecho en el tema, lo que sugiere la necesidad de realizar nuevas investigaciones en esta área del conocimiento.

El objetivo de este estudio fue determinar la presencia de anticuerpos contra Rickettsia sp., del GFM en equinos provenientes de 8 municipios de la Orinoquía Colombiana.

\section{MATERIALES Y MÉTODOS}

Tipo de estudio y muestras. Se realizó un estudio descriptivo, de corte transversal, en 246 sueros equinos provenientes de 8 municipios de la Orinoquía. Los sueros hacían parte del inventario del banco de sueros del Laboratorio de Reproducción y Genética Animal de la Universidad de Los Llanos. Las muestras habían sido obtenidas de equinos aparentemente sanos entre los meses de Julio-Agosto del 2013 y mantenidos a $-70^{\circ} \mathrm{C}$ en un ultracongelador (Revco ${ }^{\circledR}$, Asheville, NC, USA). La recolección de los sueros se acompañó con la toma de información sobre edad, sexo, raza y actividad zootécnica. 


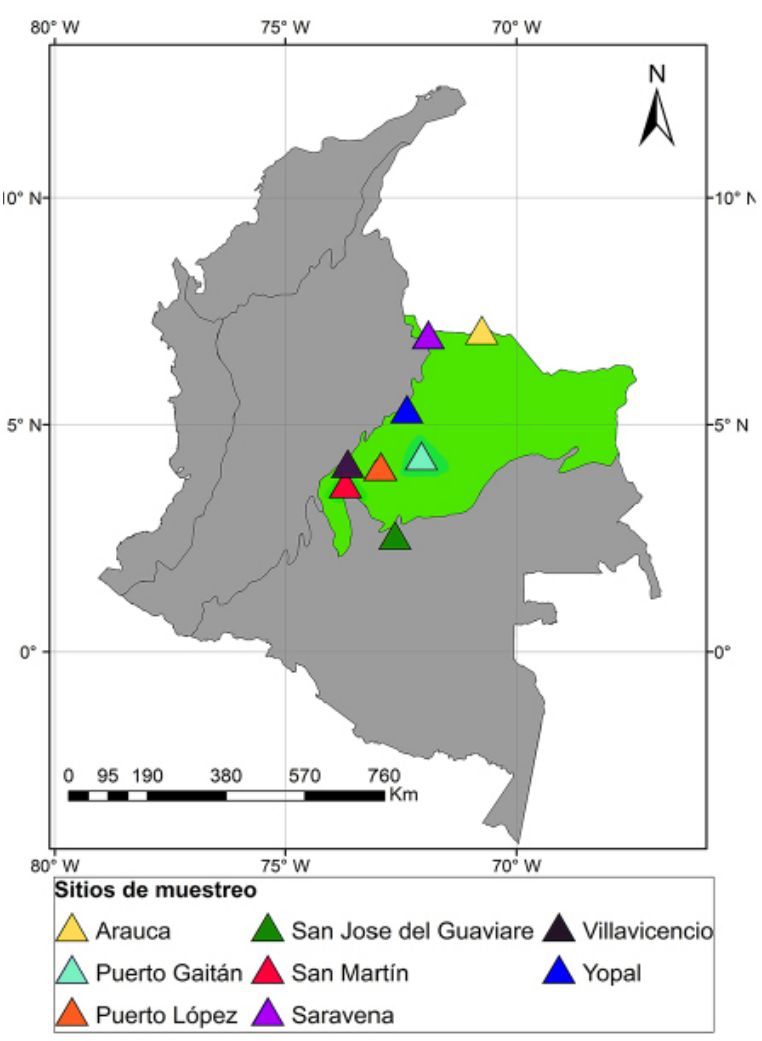

Figura 1. Map of Colombia highlighting the Colombian Orinoquia region (Green) and the municipalities where samples were collected (Triangles).

The Indirect Immunofluorescence Assay (IFA). The IFA technique was used, in which plates of 12 testing holes sensitized with antigen from $R$. rickettsia Taiaçu strain were used along with positive and negative equine controls, kindly donated by Dr. Marcelo B. Labruna from the University of Sao Paulo, Saõ Paulo, Brasil. The testing holes were blocked with $20 \mu \mathrm{l}$ of bovine serum albumin (BSA) to $1 \%$ in phosphate buffered saline (PBS), for 15 minutes. Subsequently, the BSA was removed and the testing plate was allowed to dry at room temperature. To each testing hole, $20 \mu \mathrm{l}$ of test serum was added in a dilution of 1:64 in sample diluent (PBS with $1 \%$ BSA and $0.1 \%$ tween 20). A positive and negative equine control was included in each of the processed test plates. After incubation for 30 minutes at $37^{\circ} \mathrm{C}$ in a moist chamber, and four, five-minute washes in PBS and 1\% Tween 20, $20 \mu \mathrm{l}$ of conjugate were added (Anti-horse IgG A6917 - Siga, St Louis, USA), marked with fluorescein isothiocyanate (FITC), for each test hole, at a dilution of $1: 400$ in sample diluent, which was incubated for 30 minutes at $37^{\circ} \mathrm{C}$ in a moist chamber. Later, the four washes were repeated and they were mounted for reading. The seroreactivity was
Los sueros provenían de los municipios de Villavicencio (8.2\%), Puerto López $(21.1 \%)$, Puerto Gaitán (6.1\%), Yopal $(21.1 \%)$, San Martín (10.6\%), San José del Guaviare (16.7\%), Saravena $(7.3 \%)$ y Arauca $(9,1 \%)$ figura 1 .

Prueba de Inmunofluorescencia Indirecta (IFI). Se utilizó la técnica de IFI, para lo cual se utilizaron placas de 12 pozos sensibilizadas con antígeno de $R$. rickettsii cepa Taiaçu y controles positivos y negativos de equinos, gentilmente donadas por el Dr. Marcelo B. Labruna de la Universidad de Sao Paulo, Saõ Paulo, Brasil. Se realizó un bloqueo de los pozos con $20 \mu \mathrm{l}$ de albumina sérica bovina (ASB) al $1 \%$ en buffer fosfato salino (BFS), durante 15 minutos, posteriormente se retiró la ASB y se dejó secar la placa a temperatura ambiente. Se adicionó a cada pozo $20 \mu \mathrm{l}$ del suero problema en una dilución de $1: 64$ en diluyente de muestra (BFS con $1 \%$ ASB y $0.1 \%$ Tween 20 ), se incluyó un control positivo y negativo de equino en cada una de las placas procesadas. Después de incubar durante 30 minutos a $37^{\circ} \mathrm{C}$ en cámara húmeda y de cuatro lavados de 5 minutos con BFS más $0.1 \%$ Tween 20, se adicionó $20 \mu \mathrm{l}$ del conjugado (Anti-IgG equino A6917 - Sigma, St Louis, USA), marcado con Isotiocianato de Fluoresceína (FITC), por cada pozo, a una dilución de 1:400 en diluyente de muestra, que se incubó durante 30 minutos a $37^{\circ} \mathrm{C}$ en cámara húmeda. Posteriormente se realizaron nuevamente los 4 lavados y el montaje para la lectura. La seroreactividad se observó en un microscopio de Fluorescencia (Nikon EFD- $3^{\circledR}$, Tokio, Japan) a un aumento de $100 \mathrm{X}$ y una excitación de 450 a $500 \mathrm{~nm}$ de longitud de onda. Las muestras se diagnosticaron como positivas o negativas mediante comparación con los controles. Los sueros positivos a la dilución $1: 64$, fueron titulados en diluciones dobles hasta que se volvieron negativos (14).

Análisis estadístico. Se realizó un análisis descriptivo para las variables de procedencia, sexo, raza, edad, actividad zootécnica y positividad a la IFI. Se exploraron posibles asociaciones entre la reactividad serológica y las variables independientes, utilizando una prueba Chi cuadrado y los resultados obtenidos, se analizaron mediante el software de Análisis Estadístico SPSS (Statistical Package for the Social Sciences) Statistics 21.

\section{RESULTADOS}

La población total de equinos estaba compuesta por 106 machos y 140 hembras. La edad promedio de los animales fue 5.2 años, con una edad mínima de 6 meses y máxima de 12 
observed under a fluorescent microscope (Nikon EFD- $3^{\circledR}$, Tokio, Japan) at a $100 \mathrm{X}$ magnification and a 450-500 nm excitation. The samples were identified as positive or negative by comparing them with the controls. The positive sera at a dilution 1:64 were tittered in double dilutions until they became negative (14).

Statistical analysis. A descriptive analysis was made of the variables: origin, sex, breed, age, zootechnical activity and positivity to IFA. Possible associations between serological reactivity and independent variables were explored, using a Chi-square test and the obtained results, and were analyzed using the statistical analysis software SPSS (Statistical Package for the Social Sciences) Statistics 21.

\section{RESULTS}

The total equine population was composed of 106 males and 140 females. The average age of the animals was 5.2 years, with a minimum age of 6 months and a maximum age of 12 years. The breeds included were: the Silla Argentina $(10.5 \%)$, the Cuarto de Milla $(7.5 \%)$ and the Colombian Crillo (82\%). Their zootechnical activity was classified as animals for breeding $(12 \%)$, field work $(80 \%)$ and sport $(8 \%)$. The general seropositivity was $(2.85 \% ; 7 / 246)$, four of the positive sera showed titers of $1: 64$ and the remaining 3 titers of $1: 128$.

Of the 7 positive sera, 5 (71.4\%) were males and $2(28.6 \%)$ were female. In terms of breed, $6(85.7 \%)$ were Criollo and $1(14.3 \%)$ Silla Argentina. In terms of age, there were 2 (28.6\%) in the $0-3$ year range, $1(14.3 \%)$ in the $3-6$ year range, $3(42,8 \%)$ in the $6-9$ year range and 1 $(14.3 \%)$ in the $9-12$ year range. Regarding the livestock, $6(85.7 \%)$ corresponded to working animals and $1(14.3 \%)$ was dedicated to breeding. No association between seropositivity and variables such as breed ( $p: 0.61)$, sex ( $p$ : $2.36)$, age ( $p: 0.87)$ and zootechnical activity ( $p$ : $0.65)$ were found.

A picture of the IFA positive test is found in figure 2. Seropositivity in relation to municipality (Figure3) was greatest in the municipalities of Arauca $(9.1 \%)$, followed by Saravena (5.6\%) and San José del Guaviare (4.9\%).

\section{DISCUSSION}

General seropositivity found in this study on SFG Rickettsia sp. $(2.85 \% ; 7 / 246)$ is low, nonetheless, it shows that horses have contact with Rickettsia genus bacteria, possibly transmitted through años. Las razas incluidas fueron Silla Argentina $(10.5 \%)$, Cuarto de milla $(7.5 \%)$ y Criollo Colombiano $(82 \%)$, la actividad zootécnica se clasificó como animales para la reproducción $(12 \%)$, trabajo de campo $(80 \%)$ y deporte $(8 \%)$. La seropositividad general fue $(2.85 \%$; $7 / 246)$, 4 de los sueros positivos presentaron títulos de $1: 64$ y los 3 restantes títulos de $1: 128$.

De los 7 sueros positivos, 5 (71.4\%) correspondieron a machos y 2 (28.6\%) a hembras. En cuanto a la raza $6(85.7 \%)$ eran Criollos y 1 (14.3\%) Silla Argentina. En la edad $2(28.6 \%)$ estuvieron en el rango de 0 a 3 años, 1 (14.3\%) en el rango de 3 a 6 años, 3 $(42,8 \%)$ en el rango 6 a 9 años y $1(14.3 \%)$ en el rango de 9 a 12 años. Respecto a actividad zootécnica, $6(85.7 \%)$ correspondieron a animales de trabajo y 1 (14.3\%) dedicado a la reproducción. No se encontró alguna asociación entre la seropositividad con las variables raza ( $p$ : $0.61)$, sexo ( $p: 2.36)$, edad ( $p: 0.87$ ) y actividad zootécnica ( $p: 0.65)$.

Una imagen de la prueba positiva a IFI se observa en la figura 2. La seropositividad por municipio (Figura 3) fue mayor para los municipios de Arauca (9.1\%), seguido de Saravena (5.6\%) y San José del Guaviare (4.9\%).
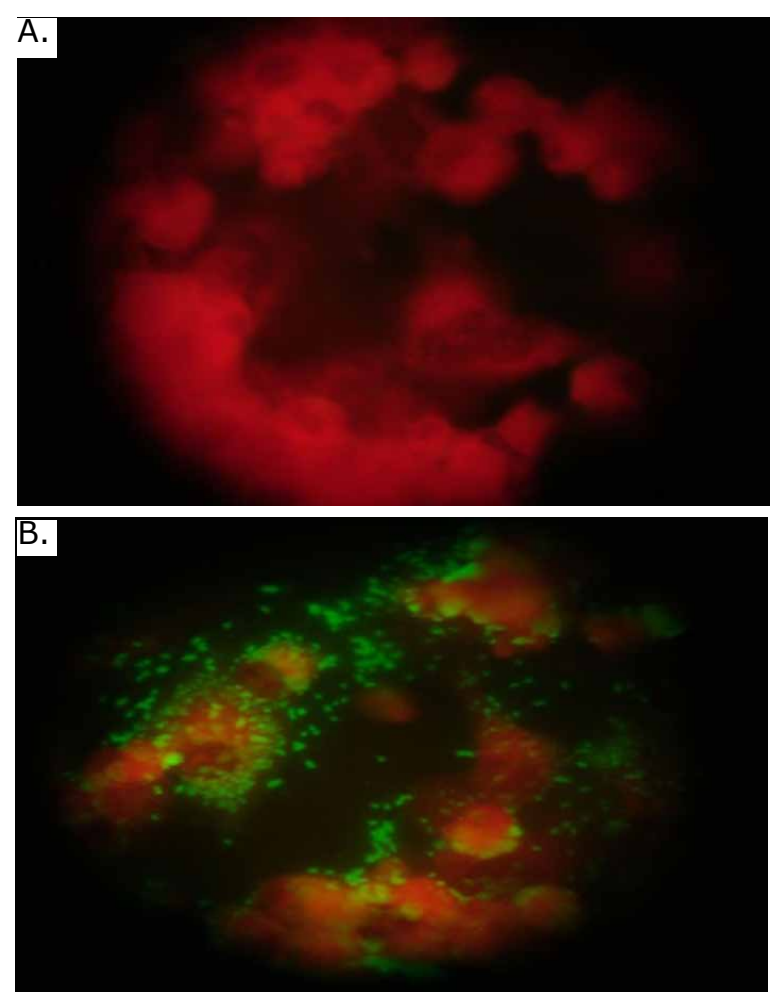

Figure 2. Indirect immunofluorescence against Rickettsia sp. from the spotted fever group (A) Negative equine serum control and (B) Positive equine serum (case No 107) Dilution of 1:64. 




Figure 3. Seropositivity by municipality against Rickettsia sp. Of the spotted fever group by means of IIT in equine sera $(n: 246)$.

contact with Amblyomma cajennense ticks, which are its principle reservoir. The presence of these antibodies essentially corresponds to IgG, which suggests a longer infection period. It should be highlighted that the principal economic activity in all the municipalities where samples were taken is animal agriculture, which is affected, principally, at the end of the dry season (February-March) when animals have decreased immunity because of nutritional stress during this time period (17).

On the other hand, the use of a single equine sample as diagnostic proof impeded ability to determine if the infection was old or new, which suggests the need for further investigations that include the use of paired tests. The absence of statistical association between serological titers and age, sex, breed and zootechnical activity agrees with Anderson (18), which could suggest that these variables do not constitute as risk factors or, the absence of association could be the result of the type of focus group and the low number of positive-testing animals.

The results of this study also suggest the need for greater epidemiological surveillance in municipalities where the greatest seropositivity was found, such as Arauca (9.1\%), Saravena $(5.6 \%)$ and San José, Guaviare $(4.9 \%)$, especially now that favorable epidemiological conditions, namely, high deforestation because of colonization and high levels of poverty, which can cause the disease to appear in humans.

The seropositivity results in our study are less than those found in horses in non-endemic areas in Brazil: (the Almirante Tamandaré-Paraná municipality) $(8.5 \%)$ (19), north of the state of Paraná $(5.5 \%)(20)$, Londrina-Paraná $(38.5 \%)$ (21) and the state of Santa Catarina (16.6\%) (22). Equally, they contrast with the results obtained in endemic regions of the same country such as: $(41 \%)$ in Juiz, Fora-Minas Gerais (23),

\section{DISCUSIÓN}

La seropositividad general encontrada en este estudio contra Rickettsia sp. del GFM (2.85\%; $7 / 246$ ) es baja, sin embargo, evidencia el contacto de los equinos con bacterias del género Rickettsia, mediado posiblemente por el contacto con garrapatas Amblyomma cajennense que es su principal reservorio. La presencia de estos anticuerpos corresponden esencialmente a IgG, como evidencia de una mayor respuesta en función del tiempo de infección. Es necesario resaltar que la principal actividad económica de todos los municipios de donde procedían las muestras, es la actividad pecuaria, la cual se ve afectada principalmente al final del verano (Febrero-Marzo) en donde los animales disminuyen su inmunidad por estrés nutricional durante esta época (17).

De otro lado, el uso de una sola muestra en los equinos como prueba diagnóstica, impidió determinar si la infección era antigua o reciente, lo que sugiere la realización de nuevos trabajos que incluyan la utilización de muestras pareadas. La ausencia de asociación estadística de los títulos serológicos con la edad, sexo, raza y actividad zootécnica coincide con Anderson (18), lo que puede sugerir que estas variables no se constituyen en factores de riesgo o que la ausencia de asociación puede ser resultado del tipo de muestreo y el bajo número de animales positivos.

Los resultados de este estudio, plantean además la necesidad de una mayor vigilancia epidemiológica en los municipios en donde se encontró la mayor seropositividad como Arauca (9.1\%), Saravena $(5.6 \%)$ y San José del Guaviare (4.9\%), ya que presentan condiciones epidemiológicas favorables para que la enfermedad se presente en humanos, entre ellas, alta deforestación por la acción colonizadora y altos niveles de pobreza.

Los resultados de la seropositividad en nuestro estudio son menores a los encontrados en equinos en áreas no endémicas en Brasil (municipalidad Almirante Tamandaré-Paraná) $(8.5 \%)(19)$ Norte del Estado de Paraná (5.5\%) (20), Londrina-Paraná (38.5\%) (21) y el Estado de Santa Catarina (16.6\%) (22). Igualmente, contrastan con los resultados obtenidos en regiones endémicas de ese mismo país como (41\%) en Juiz de Fora-Minas Gerais (23), (77.3\%) en el municipio de Pedreira-Sao Paulo (14) y $100 \%$ en Itabira-Minas Gerais (24).

La seropositividad general $(2.85 \%)$ es menor a la reportada en equinos de Villeta, Cundinamarca que fue de $(16.3 \%)$ considerada una área 
(77.3\%) in the municipality of Pedreira-Sao Paulo (14) and $100 \%$ in Itabira-Minas Gerais (24).

General seropositivity $(2.85 \%)$ is less than what was reported in horses in Villeta, Cundinamarca, which was (16.3\%) considered an endemic area, where 3 species of ticks, $A$. cajennense, Rhipicephalus sanguineus and Dermacentor nitens, have been identified as having an impact on the transmission of Rickettsia rickettsii (25). These are the same species that have been identified in the Orinoquia region (26). "Clarifying from a public health perspective that A. cajennense is the species with the greatest potential of transmitting Rickettsia spp. to humans."

Despite the fact that our study did not include other sentinel animals for $R$. rickettsii such as canines (Canis lupus familiaris) and capybaras (Hydrochaeris hydrochaeris) among others $(27,28)$, the abundant wildlife in the surveyed municipalities suggests their inclusion in future studies. Although it is made evident that horses on their own have value as sentinels, given that they are principal hosts of $A$. cajennense, one of the principal vectors for $R$. rickettsii (13), suggests that the detection of antibodies in horses would be a good indicator for determining the circulation of $R$. rickettsii in areas where humans can be exposed to $A$. cajennense.

In a study in Brazil where, in addition to humans, horses and canines were sampled, a pattern was found of serological response characterized by a high frequency of positive horses, followed by dogs and a low frequency in humans (14). Contrarily, this pattern has not been reported in other studies (8). None the less, a high association between tick infestation among humans and the presence of $A$. cajennense in horses (29) has been displayed; such seems to be the case of high seropositivity in humans, found by Miranda et al (16).

Even without the use of sentinel animals, the high frequency of seropositivity in humans, such as found in the Puerto López vicinity (59\%) (16), indicates the circulation of SFG Rickettsia sp., which requires special attention from municipal and departmental health authorities of the entire Orinoquia region.

Even though there have been no confirmed fatal cases in the region, possibly due to the fact it manifests similar clinical signs to other tropical diseases, the differential diagnosis of rickettsiosis should be obligatorily included in the case of undiagnosed febrile cases in the population. An additional aspect that could explain the absence endémica, en donde además se han identificado tres especies de garrapatas $A$. cajennense, Rhipicephalus sanguineus y Dermacentor nitens que tienen importancia en la transmisión de Rickettsia rickettsii (25). Las mismas especies que han sido identificadas en la región de la Orinoquía (26). "Aclarando desde una perspectiva de salud pública que la $A$. cajennense es la especie con mayor potencial en la transmisión de Rickettsia spp. a humanos."

A pesar que nuestro estudio no incluyó otros animales centinelas para $R$. rickettsii como caninos (Canis lupus familiaris) y chigüiros (Hydrochaeris hydrochaeris) entre otros (27, 28), la abundante fauna silvestre en los municipios encuestados, sugiere su inclusión en nuevos estudios. Aunque se hace evidente que los equinos por si solos tienen valor como animales centinelas, dado que son los principales hospederos de $A$. cajennense uno de los principales vectores de $R$. rickettsii (13), sugiriendo que la detección de anticuerpos en los equinos serian un buen indicador para determinar la circulación de $R$. rickettsii en áreas en donde los humanos pueden llegar a estar expuestos a $A$. cajennense.

En un estudio en Brasil en donde se muestrearon además de los humanos, equinos y caninos, se encontró un patrón de respuesta serológica caracterizada por una alta frecuencia de animales positivos en equinos, seguidos de los perros y una baja frecuencia en los humanos (14), contrariamente este patrón no ha sido reportado en otros estudios (8). No obstante, se ha demostrado una alta asociación entre la infestación de humanos por garrapatas, con la presencia de $A$. cajennense en caballos (29), tal parece ser el caso de la alta seropositividad en humanos encontrada por Miranda et al (16).

Aún sin el uso de animales centinelas, la alta frecuencia de seropositividad en humanos, como la encontrada en cercanía a Puerto López, (59\%) (16) señala la circulación de Rickettsia sp. del GFM, lo cual requiere una atención especial por parte de las autoridades de salud municipales y departamentales de toda la Orinoquía.

Aunque en la región no se han confirmado casos letales, posiblemente por la similitud de los signos clínicos con otras enfermedades tropicales, el diagnóstico diferencial para rickettsiosis debería ser incluido de forma obligatoria ante la presencia de eventos febriles sin diagnóstico en la población. También un aspecto adicional que podría explicar la ausencia de casos letales es la circulación de diversas especies de Rickettsia spp. de menor patogenicidad y que confieren 
of fatal cases is the circulation of diverse species of Rickettsia spp. of lesser virulence and which lend cross protection against the most virulent of the SFG which is $R$. rickettsii.

None the less, since the presence of antibodies against Rickettsia sp. from the SFG in horses were identified in this study, this information should be analyzed with care, given that it is difficult to predict that there will be cases in the near future in these municipalities. Recently, experimental studies showed that $A$. cajennense is scarcely efficient for maintaining $R$. rickettsii for successive tick generations over time (30). This possibility explains why there was not a high frequency of sporadic outbreaks over time in endemic zones. In the same way, crossreactivity between other species of Rickettsia causes overestimation of seroprevalence when a single species is studied (8).

Finally, this study confirms the circulation of SFG Rickettsia sp. in the municipalities of the Orinoquia region, findings that adhere to those of Miranda et al (16) in the proximity of Puerto López and by the Ministry of Health in samples of the department of Guaviare (15), and suggests the need to maintain surveillance of possible undiagnosed febrile cases with the objective of avoiding fatalities. Without a doubt, the different ecological conditions of each municipality or each region can be a principle factor regulating the presence of bacteria and, consequentially, the presence of disease.

\section{Acknowledgements}

COLCIENCIAS for their financial support to this project. Dr. Juan D. Rodas and members of the emergent and re-emergent zoonoses branch of the UDEA Centauro group and Unillanos GIRGA group. To the UDEA program "201324 sustainability". Dr. Marcelo Labruna Sao Paulo University, Brasil. Article derived from an interinstitutional cooperation agreement 0873-2012-Young researchers of Colciencias, signed by Universidad de Antioquia and Universidad de los Llanos.

Conflict of interests. The authors declare that there is no conflict of interests. protección cruzada contra la más patógena del GFM que es $R$. rickettsii.

No obstante, que se identificó la presencia de anticuerpos contra Rickettsia sp., del GFM en equinos en este estudio, esta información deber ser analizada con reserva, puesto que es difícil predecir que en estos municipios se vayan a presentar casos en un futuro cercano. Recientemente, estudios experimentales demostraron que $A$. cajennense tiene una baja eficiencia para mantener a $R$. rickettsii por generaciones sucesivas de garrapatas a través del tiempo (30). Esto posiblemente explique porque en zonas endémicas no se presentan con mayor frecuencia brotes esporádicos a través del tiempo. De igual forma la reactividad cruzada con otras especies de Rickettsia, hace que la seroprevalencia puede ser sobreestimada cuando se estudia una sola especie (8).

Se evidencia finalmente en este estudio la circulación de Rickettsia sp. del GFM, en municipios de la Orinoquía, hallazgos que se suman a los encontrados por Miranda et al (16) en cercanía a Puerto López y por el Ministerio de Salud en muestras del departamento del Guaviare (15) y plantea la necesidad de mantener la vigilancia ante los posibles eventos febriles sin diagnóstico, con el objeto de evitar casos fatales. Sin duda las diferentes condiciones ecológicas de cada municipio o de cada región puede ser el principal factor que regule la presencia de la bacteria y consecuentemente la presencia de la enfermedad.

\section{Agradecimientos}

COLCIENCIAS por el apoyo financiero a este proyecto. Dr. Juan D. Rodas e integrantes de la línea de zoonosis emergentes y reemergentes del grupo Centauro de la UDEA y grupo GIRGA de Unillanos. Al programa "sostenibilidad 20132014" de la UDEA. Dr. Marcelo Labruna Universidad de Sao Paulo, Brasil. Articulo derivado del convenio de Cooperación 0873-2012-Jóvenes investigadores Colciencias modalidad interistitucional suscrito entre la Universidad de Antioquia y la Universidad de los Llanos.

Conflicto de intereses. Los autores declaran no tener ningún conflicto de intereses. 


\section{REFERENCES}

1. Gillespie JA, Williams K, Shukla M, Snyder EE, Nordberg EK, Ceraul SM, et al. Rickettsia Phylogenomics: unwinding the intrincacies of obligate intracelular life. Plos ONE 2008; 3(4):e2018.

2. Labruna MB. Ecology of Rickettsia in South America. Ann N Y Acad Sci 2009; 1166:156-166.

3. Walker DH. Rickettsia rickettsii: as virulent as ever. Am J Trop Med Hyg 2002; 66(5):448-449.

4. Walker DH. Rickettsiae and rickettsial infections: the current state of knowledge. Clin Infect Dis 2007; 45(Suppl 1):S39-S44.

5. Galvão MAM. Rickettsiosis as a public health problem in South America. Biomédica 2011; 31(Supl):11-73

6. Patiño L, Afanador A, Paul JHA. Spotted fever in Tobia, Colombia. Am J Trop Med $1937 ; 17: 639-653$

7. Hidalgo $M$, Orejuela L, Fuya $P$, Carrillo $P$, Hernández J, Parra E, et al. Rocky Mountain spotted fever, Colombia. Emerg Infect Dis 2007; 13(7):1058-1060.

8. Acosta J, Urquijo L, Díaz A, Sepúlveda M, Mantilla G, Heredia M, et al. Brote de rickettsiosis en Necoclí, Antioquia, febrero marzo de 2006. Inf Quinc Epidemiol Nac 2006; 11(11):161-176.

9. Hidalgo M, Lizarazo DS, Ovalle MV, Castañeda E. Brote de rickettsiosis en Los Córdobas, departamento de Córdoba, febrero-marzo 2007. Inf Quinc Epidemiol Nac 2007a; 12(24):367-378

10. Pacheco O, Giraldo R, Martínez M, Hidalgo M, Galeano A, Echeverri I, et al. Estudio de brote febril hemorrágico en el corregimiento de Alto de Mulatos - Distrito Especial Portuario de Turbo, Antioquia, enero de 2008. Inf Quinc Epidemiol Nac 2008; 13(10):145-160

11. Pinter AM, Horta C, Pacheco RC, MoraesFilho J, Labruna MB. Serosurvey of Rickettsia spp. in dogs and humans from an endemic area for Brazilian spotted fever in the State of São Paulo, Brazil: Cad Saude Publica 2008; 24:247-252.
12. Milagres BS, Padilha AF, Barcelos RM, Gomes GG, Montandon CE, Pena DC, et al. Rickettsia in synanthropic and domestic animals and their hosts from two areas of low endemicity for Brazilian spotted fever in the eastern region of Minas Gerais. Brazil Am J Trop Med Hyg 2010; 83(6):1305-1307

13. Sangioni LA, Horta MC, Vianna MCB, Gennari SM, Soares RM, Galvao M, et al. Rickettsial infection in animals and Brazilian Spotted Fever endemicity. Emerg Infec Dis 2005; 11(2):265-270.

14. Horta MC, Labruna MB, Sangioni LA, Vianna CB, Gennari SM, Galvão M. et al. Prevalence of antibodies to spotted fever group rickettsiae in humans and domestic animals in a brazilian spotted fever-endemic area in the state of São Paulo, Brazil: serologic evidence for infection by rickettsia rickettsii and another spotted fever group rickettsia. Am J Trop Med Hyg 2004; 71(1):93-97

15. Suárez R, Hidalgo M, Niño N, González C, Vesga JF, Orejuela $L$, et al. Las rickettsias como agentes etiológicos de entidades febriles no diagnosticadas en Colombia. Universidad de Los Andes, Facultad de Ciencias Sociales, Departamento de Antropología, CESO, Ediciones Uniandes, 2008. 6:25-26.

16. Miranda JL, Sánchez L, Amaya K, Mattar S. Primera prueba serológica de Rickettsia $s p$. del grupo de las fiebres manchada en el departamento del Meta. Biomédica 2011; 31(Supl):103-113.

17. Corpoica. Red de Garrapatas y enfermedades trasmitidas por garrapatas para América Latina y el Caribe. [Fecha de acceso Septiembre de 2014]. URL: http://www. corpoica.org.co/SitioWeb/redectopar/ preguntas.asp.

18. Andersson E. Seroprevalence of Rickettsia rickettsii and Rickettsia amblyommii in horses in three municipalities in the state of Pará, Brazil. Examensarbete Inom Veterinärprogrammet, Uppsala 2013; 62:1-19. http://stud.epsilon.slu.se/5630/1/ Andersson E 130520.pdf 
19. Gonçalves Batista F, Matos da Silva D, Green KT, de Lorenzi Tezza LB; Pereira de Vasconcelos S, Soares de Carvalho SG. et al. Serological survey of Rickettsia sp. in horses and dogs in an non-endemic area in Brazil. Rev Bras Parasitol Vet 2010; 19(4):205-209.

20. Tamekuni K, Toledo $\mathrm{R}$, Silva Filho MF, Haydu VB, Pacheco RC, Cavicchiol JH. et al. Serosurvey of antibodies against spotted fever group Rickettsia spp. in horse farms in Northern Paraná, Brazil. Rev Bras Parasitol Vet Jaboticabal 2010; 19(4):259-261

21. Toledo RS, Tamekuni K, Silva Filho M F, Haydu V B, Barbieri ARM, Hiltel AC, et al. Infection by Spotted Fever Rickettsiae in People, Dogs, Horses and Ticks in Londrina, Parana State, Brazil. Zoonoses Public Health $2011 ; 58(6): 416-423$

22. Medeiros AP, Moura AB, Souza AP, Bellato V, Sartor AA, Vieira-Neto A, et al. Antibodies against rickettsiae from spotted fever groups in horses from two mesoregions in the state of Santa Catarina, Brazil. Arq Bras Med Vet Zootec 2013; 65(6):1713-1719.

23. Pacheco RC, Moraes-Filho J, Guedes E, Silveira I, Richtzenhain LJ, Leite RC, Labruna MB. Rickettsial infections of dogs, horses and ticks in Juiz de Fora, southeastern Brazil, and isolation of Rickettsia rickettsii from Rhipicephalus sanguineus ticks. Med Vet Entomol 2011; 25:148-155

24. Vianna MCB, Horta MC, Sangioni LA, Cortez A, Soares RM, Mafra CL. et al. Rickettsial spotted fever in Capoeirão village, Itabira, Minas Gerais, Brazil Rev Inst Med Trop S Paulo 2008; 50(5):297-301.
25. Hidalgo M, Vesga JF , Lizarazo D, Valbuena GA. Survey of Antibodies against Rickettsia rickettsii and Ehrlichia chafeensis in Domestic Animals from a Rural Area of Colombia. Am J Trop Med Hyg 2009; 80(6):1029-1030.

26. Evans DE. Boophilus microplus Ecological Studies and a Tick Fauna Synopsis Related to the Developing Cattle Industry in the Latin American and Caribbean Region. [Tesis doctoral]. Cnaa/NE. London Polytechnic United Kingdom; 1978.

27. Labruna MB, Romero M, Martins TF, Tobler M, Ferreira F.Ticks of the genus Amblyomma (Acari: Ixodidae) infesting tapirs (Tapirus terrestris) and peccaries (Tayassu pecari) in Peru. Syst Appl Acarol 2010; 15:109-112.

28. Krawczak FS, Nieri-Bastos FA, Nunes FP, Soares JF, Filho JM, Labruna MB. Rickettsial infection in Amblyomma cajennense ticks and capybaras (Hydrochoerus hydrochaeris) in a Brazilian spotted fever-endemic area. Parasites \& Vectors 2014; 7:1-7

29. Labruna MB, Kerber CE, Ferreira F, Faccini JHL, De Wall DT, Gennari SM. Risk factors to tick infestations and their occurrence on horses in the state of São Paulo. Brazil Vet Parasitol 2001; 97(1):1-14.

30. Soares JF, Soares HS, Barbieri AM, Labruna MB. Experimental infection of the tick Amblyomma cajennense, Cayenne tick, with Rickettsia rickettsii, the agent of Rocky Mountain spotted fever. Med Vet Entomol 2012; 26(2):139-15. 